\title{
Utilization of Coconut Oil (Cocos nucifera L.) for Provoke The Presence of Ants (Hymenoptera: Formicidae)
}

\author{
Ari Sugiarto \\ Email: sugiartoari13@gmail.com
}

\begin{abstract}
Ants have an interest in carbohydrates based on studies that have been done by people. Based on other studies showing that coconut oil residues still have a high carbohydrate content. Need to do research on the use of coconut oil to provoke the presence of ants. The results of this study can show the potential of coconut oil to provoke the presence of certain ants. Testing of coconut oil to provoke the presence of these ants is carried out at the location of litter, bush, and terrain in Serdang Menang Village plantation. The selection of test sites in litter, bush, and terrain allows for differences in ant species in that location. The method used is by applying coconut oil to the cotton and then placing it in the location of litter, bush, and terrain. The results of the study found ant species Dolichoderus sp. and Tapinoma sp. interested in coconut oil which is placed in the location of litter, bush, and terrain. It is estimated that ant species in the locations of litter, bush, and terrain are not only Dolichoderus sp. and Tapinoma sp. Coconut oil can provoke the presence of Dolichoderus sp. and Tapinoma sp. in the location of litter, bush, and terrain in Serdang Menang Village plantation, this could indicate the potential of coconut oil as an attractant for the ant species Dolichoderus sp. and Tapinoma sp.
\end{abstract}

Keywords: Ants, Coconut oil, Dolichoderus sp., Tapinoma sp.

\section{Introduction}

Coconut (Cocos nucifera L.) is native to Brunei, Indonesia, Cambodia, Laos, Malaysia, Myanmar, Philippines, Singapore, Thailand and Vietnam. Coconut can flourish in coastal areas that have tropical and subtropical climates and can also grow far from coastal areas. One of the uses of coconut is to use the fruit for coconut oil. Coconut oil residues contain $20 \%$ protein, $45 \%$ carbohydrates, $11 \%$ fiber, fat, minerals and moisture (Orwa et al., 2009).

Carbohydrates have links to ant colonies, such as the study conducted by Dussutour and Simpson (2008) which showed that the regulation of the concentration of sugar solution affected the ant colonies. According to Detrain and Jacques (2014), feeding sucrose is faster in the ant response than the response to feeding melezitose, fructose, and glucose.

Need to do research on the benefits of coconut oil to provoke the presence of ants. The results of this study can also see the potential of coconut oil as an attractant for certain ant species.

\section{Reseach Methods}

Extraction of coconut oil is carried out by hot extraction methods (Mikołajczak, 2017). The criterion of the extracted coconut is that it has shoots, which show a lot of oil contained in the endosperm. This part of the endosperm is mashed, then enough water is added to get starch. The mashed endosperm and added water are then squeezed to get starch water. The starch water that has been obtained is then heated to form coconut oil.

Coconut oil that has been obtained from the extraction process is used to provoke the presence of ants. Coconut oil is applied to cotton, then the cotton that has been applied to coconut oil is placed on the location of litter, bush, and terrain. The selection of this location saw the results of Haneda and Nisfi research (2015) which showed a difference in the number of ant species in different 
ecosystems. The selection of coconut oil testing locations to provoke the presence of these ants was carried out at Serdang Menang Village Plantation, Sirah Pulau Padang Sub-district, Ogan Komering Ilir District. The testing time is 1 hour to provoke the presence of ants in a large scope, considering the results of research by Detrain and Jacques (2014), within 10 seconds the ants can find the source of sugar in a small scope.

Identification of ant species obtained is done by matching the species of ants that have been identified.

\section{Results and Discussion}

Based on the research conducted, the results are:

Table 1. Ant species interested in coconut oil placed in litter, bush, and terrain

\begin{tabular}{ll}
\hline Location & Species \\
\hline Litter & $\begin{array}{l}\text { Dolichoderus } \mathrm{sp} . \\
\text { Tapinoma } \mathrm{sp} .\end{array}$ \\
\hline Bush & $\begin{array}{l}\text { Dolichoderus } \mathrm{sp} . \\
\text { Tapinoma } \mathrm{sp} .\end{array}$ \\
\hline Terrain & Tapinoma $\mathrm{sp}$. \\
\hline
\end{tabular}

Two ant species were found, namely Dolichoderus sp. and Tapinoma sp. who are interested in coconut oil in all locations. Ant species that are attracted to coconut oil location in litter and bush, namely Dolichoderus sp. and Tapinoma sp., while ant species are attracted to coconut oil at the location of the terrain is Tapinoma sp.

Species that exist in litter, bush, and terrain locations in the Serdang Menang Village plantation are certainly more than ant species that are interested in coconut oil. It can be assessed that on ant inventory in other regions as conducted by Lutinski et al. (2017), found 52 species of ants in the Atlantic forest, South Brazil. Ranny et al. (2015), found 12 species of ants in the Lubuk Minturun dragon fruit plantation. Franco and Rodrigo (2018), found 163 species in the Paraná meadow. According to Fisher (2005), the effects of habitat can affect the efficiency of the method used to catch ants.

Dolichoderus sp. and Tapinoma sp. allowing interest in coconut oil. Some ant species are attracted by sugar as research conducted by Detrain and Jacques (2014), shows that Lasius niger has an interest in sugar (sucrose). Dussutour and Simpson (2008), there is an effect of sugar (sucrose) on the growth of Rhytidoponera metallica colonies.

The content of coconut oil residues is $20 \%$ protein, $45 \%$ carbohydrates, $11 \%$ fiber, fat, minerals and moisture (Orwa et al., 2009). According to Mikołajczak (2017), coconut oil contains fatty acids (caproic acid, caprylic acid, capric acid, lauric acid, myristic acid, palmitic acid, stearic acid, oleic acid, linoleic acid, and linolenic acid), sterols (campesterol, stigmasterol, and $\beta$-sitosterol), tocols (tocopherols $(\alpha-\mathrm{T}, \beta-\mathrm{T}, \gamma-\mathrm{T}, \Delta-\mathrm{T})$ and tocotrienols $(\alpha-\mathrm{T} 3, \beta-\mathrm{T} 3, \gamma-\mathrm{T} 3, \Delta-\mathrm{T} 3)$ ), and phenolic acids (protocatechuic acid, vanillic acid, caffeic acid, syringic acid, ferulic acid, p-coumaric acid, gallic acid, and p-hydroxybenzoic acid).

Other research needs to be done to find out the specific compounds that cause the ant species Dolichoderus sp. and Tapinoma sp. interested in coconut oil.

\section{Conclution}

Coconut oil can provoke the presence of Dolichoderus sp. and Tapinoma sp. in the location of litter, bush, and terrain in Serdang Menang Village plantation, this could indicate the potential of coconut oil as an attractant for the ant species Dolichoderus sp. and Tapinoma sp.

\section{References}

Detrain, C and Jacques, P. 2014. Sensitivity and Feeding Efciency of The Black Garden Ant Lasius niger to Sugar Resources. Journal of Insect Physiology. 64(1): 74-80. 
Dussutour, A and S.J. Simpson. 2008. Carbohydrate Regulation in Relation to Colony Growth in Ants. The Journal of Experimental Biology. 211(1): 2224-2232.

Fisher, B.L. 2005. A Model for a Global Inventory of Ants: A Case Study in Madagascar. Proceedings of The California Academy of Sciences. 56(8): 86-97.

Franco, W and Rodrigo, M.F. 2018. First Standardized Inventory of Ants (Hymenoptera: Formicidae) in the natural grasslands of Paraná: New records for Southern Brazil. Papéis Avulsos de Zoologia. 58(12): 1-8.

Haneda, N.F and Nisfi, Y. 2015. Komunitas Semut (Hymenoptera: Formicidae) pada Empat Tipe Ekosistem yang Berbeda di Desa Bungku Provinsi Jambi. Jurnģl Silvikultur Tropika. 6(3): 203-209.

Lutinski, J., Cladis, J.L., Carin, G., Maria, A.B., and Flavio, R.M.G. 2017. Richness and Structure of Ant Assemblies (Hymenoptera: Formicidae) in Atlantic Forest in Southern Brazil. Anais $d a$ Academia Brasileira de Ciências. 89(4): 2719-2729.

Mikołajczak, N. 2017. Coconut Oil in Human Diet - Nutrition Value and Potential Health Benefits. Journal of Education, Health and Sport. 7(9): 307-319.

Orwa, C., A. Mutua., Kindt, R., Jamnadass R., and S. Anthony. 2009 Agroforestree Database:a tree reference and selection guide version 4.0. (Online). http://www.worldagroforestry.org /sites/treedbs/treedatabases.asp. Accessed on November 1, 2018.
Ranny., Henny, H., and Dahelmi. 2015. Inventarisasi Semut yang Ditemukan pada Perkebunan Buah Naga Lubuk Minturun, Kota Padang dan Ketaping, Kabupaten Padang Pariaman, Sumatera Barat. Jurnal Biologi Universitas Andalas. 4(1): 57-64. 